\title{
Evaluation of Risk Management Strategies in Government Institutions: Case Study on Abu Dhabi Municipalities
}

\author{
Rana Zain Ul Abidin ${ }^{1} \quad$ Rabia Qammar $^{1^{*}} \quad$ Atef Alkhawaldah $^{2}$ \\ 1.ILMA University, formerly IBT, Karachi, Pakistan \\ 2.College of Business, Abu Dhabi University
}

\begin{abstract}
Government institution's failure around the world has motivated researchers to investigate the link between risk management strategies and performance of government institutions. The prime objective of this study is to examine the impact of risk management framework implementation (RMFI) and risk management success factors (RMSF) on the performance of government institution in Abu Dhabi. Survey data on 163 employees from three Abu Dhabi Municipalities (Abu Dhabi City, Al Ain City Municipality, Al Dhafra Region Municipality) were collected. PLS-Sem 3.0 software were applied to test hypotheses. The findings of this research release that RMFI, and RMSF has significant effects on the performance of Abu Dhabi municipalities. The study recommends that government firms and regulatory agencies should promote sound risk culture with a view to increase risk awareness, establish a robust information management system for comprehensive risk analysis and reporting, devise internal risk knowledge sharing strategies to boost staff capabilities and entrench effective leadership role to handle complex firms' operational activities.
\end{abstract}

Keywords: Risk management framework implementation, risk management success factors, government institute firm performance

DOI: $10.7176 / \mathrm{JCSD} / 56-03$

Publication date: February $29^{\text {th }} 2020$

\section{Introduction}

The global economic meltdown is an indicator that regulatory agencies need to increase their monitoring and surveillance capabilities to ensure a sound global financial system (Nicolas, 2012). Government institutions are among the most significant economic drivers that improve the welfare of individuals by supporting the ability of households and business entities to hold and transfer financial assets (CBN, 2010). Despite, the role of this important sector, government institutions around the world have witnessed monumental challenges in carrying out effective and efficient intermediation (Oladapo \& Richard, 2012). For example, the market capitalization of the global equity markets dropped from US51 trillion dollars to US21 trillion dollars, a decrease of 56 percent in 2009 (Onour, 2009). These developments have negatively affected the performance of firms globally.

As a response to global failure, various government agencies had developed rules and regulations that were meant to guide firms' operational activities. The United State of America introduced Sarbanes-Oxley Act (SOX 2002) to control and protect further corporate fraud in the country (Lai \& Azizan, 2012). The Sarbanes-Oxley Act requires a top-down risk approach that includes identification, prioritising and assessment of material risks for better business performance (Daud, Yazid, \& Hussin, 2010). These regulations have prompted business firms to be relentless in identifying efficient strategies that will improve their performance and survival.

In Abu Dhabi, the government institutes are surrounded by poor risk management practices, economic distress, solvency crises and operational infractions among others (Ramady, 2013). Some of the government institutions were involved in sharp business practices that fleece shareholders investments (AlNuaimi, Shaalan, Alnuaimi, \& Alnuaimi, 2011; Reiche, 2010). Also, the introduction of various economic reforms in the country has led to the explosion of several corporate governance codes. These corporate governance conventions set the regulatory capital base that could control the risks facing the government sector and stipulate how effective monitoring will improve firm performance.

However, empirical findings have been inconsistent concerning the anticipated benefits of risk management strategy to firm's performance (Abdullah et al., 2012; Ballantyne, 2013; Mikes \& Kaplan, 2014). To resolve some of the inconsistencies in the literature, some studies have suggested the introduction of certain organisational variables (Gordon, Loeb, \& Tseng, 2009; Hafizuddin-Syah, Abdul-Hamid, Janor, \& Yatim, 2014). The CBN (2006) corporate governance report identified managerial ownership as a possible incentive that may lead to interest alignment between the management of a firm and its owners (shareholders). Since risk management strategy implementation is a board decision, the study argued that alignment of interest between board members and the owners may likely strengthen risk management decisions which may eventually improve firm performance.

Notably, the concern of the board of directors is to ensure that an effective risk management strategy is in place. It is, therefore, likely that in line with several studies (Bhagat \& Bolton, 2008; Carol Liu, Tiras, \& Zhuang, 2014; Hillman \& Dalziel, 2003; Lim \& Mccann, 2013), board equity ownership may lead to the 
alignment of interest between board members and shareholders. Hence, this alignment of interest may improve the board monitoring capacity with a view to improving firm performance (Ren, Chandrasekar, \& Li, 2012). Thus, the success of risk management strategies is expected to be supported by board equity ownership. Hence, board equity ownership may improve the monitoring ability of the board, which will lead to effective risk management strategies (Bouwens \& Verriest, 2014). Thus, it is against this background that this study will attempt to examine the impact of risk management strategies on the performance of firms in the government institutes of Abu Dhabi.

\section{Literature review}

Several sources in the literature have traced the concept of risk management to the year 1955 (Harrington \& Niehaus, 2003; Williams \& Heins, 1995). Dionne (2013) stressed that the new aspect of managing risk emerged during the mid-1950s as a substitute for insurance buying due to the high cost of insurance policy. He further asserted that organisations developed contingency planning activities and a series of risk prevention techniques within the period. During that period, risk management was not considered as an aspect of the business management process. It is simply a mechanism for taking precautionary measures to ensure the success of business operations (Kalita, 2004). There was neither quantitative practice to assess risk nor the technology available to manage and distribute it. Hence, business activities became defenseless and prone to various types of risks.

\subsection{Risk Management}

The concept of success factors has been in practice since the 1970s (Yaraghi \& Langhe, 2011). The concept refers to a systematic way of identifying the critical areas, or signposts, that require constant and careful attention of management in order to achieve higher firms' performance (Ram \& Corkindale, 2014). Rockart (1978) was among the first authors to introduce the concept of success factors in organisations. He defined success factors as "the limited number of areas in which results if they are satisfactory, will ensure competitive performance for the organisation" (Rockart, 1978, p. 12). Specifically, firms need to identify few key areas where things need to go right for the business to flourish. Freund (1988) viewed success factors as essential ingredients that are suitable for each unit of business organizations. Mcleod and Scheel (2004) defined it as “one of the firm's activities that have a strong influence on the ability of the company to meet its objective".

Since RMSF is a holistic process, this study focuses on compliance, risk management culture, risk management information, risk knowledge sharing, staff competence, innovativeness and leadership factor as important success factors that can drive business performance. These factors have received little attention in the RMSF literature stream. Moreover, Strauss and Corbin (1998) argued that success factors ought to reflect the study practical issues. As such, these success factors emerged from the practical issues raised in this study.

In order to improve organizational performance, information dissemination is expected to assist organisations to understand and manage business fortuities. Some studies have reported the positive relationship between RMIS and firm performance (Al-gharaibeh \& Malkawi, 2013; Altaany, 2013; Hashim et al., 2012). Based on these theoretical arguments between RMIS and firm performance of government institutions in Abu Dhabi, the study has come up with the following hypotheses:

Ha1: Risk management framework implementation has significant impact on firm performance of government institutions in Abu Dhabi.

Hb1: Risk culture has significant impact on firm performance

$\mathbf{H b}_{2}$ : Risk management information system has significant impact on firm performance.

Hb3: Risk knowledge sharing has significant impact on firm performance.

\subsection{Agency theory}

The complexity of modern business, stock market development and the need for organisations to allocate risk efficiently (Fama, 1980; Fama \& Jensen, 1983) have created the need for principal-agent relationships. Agency theorists have argued that in the modern corporation, conflicts of interest surfaces because of the division that exist between managers and owners (Pratt \& Zeckhauser, 1985). Fundamentally, agency theory has provided the background for understanding the contractual relationship between principals (owners) and agents (managers) in the modern business environment (Jensen \& Meckling, 1976).

In an agency relationship, the agent may pursue actions that are inconsistent with the wealth maximization interests of owners (Demsetz \& Lehn, 1985; Jensen \& Meckling, 1976). The contract has obliged the agent to ensure efficient management of risks on behalf of the principal, who is the residual claimant and the risk bearer (Fama \& Jensen, 1983). 


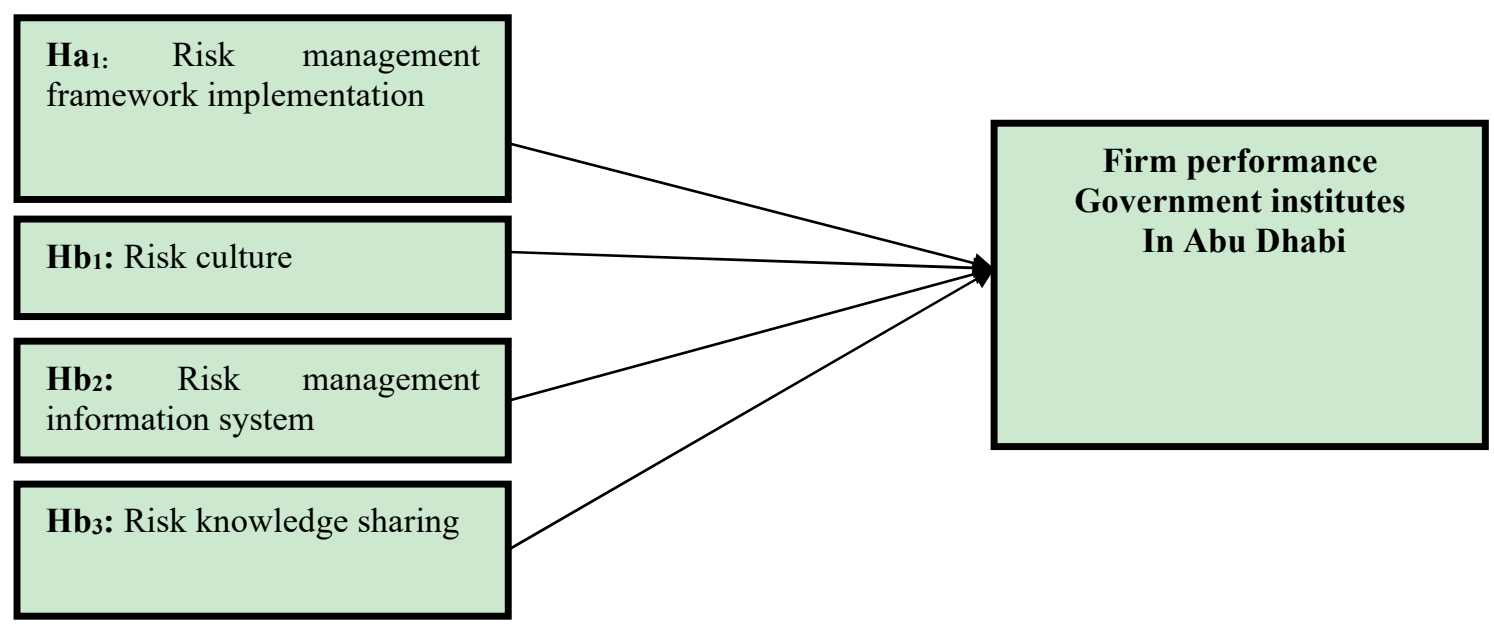

Figure 1: Conceptual Framework of risk management strategies and firm performance of government institutions in Abu Dhabi.

\section{Research Design}

A quantitative approach refers to a situation where numerical data is used to represent the phenomenon being studied (Hair Jr et al., 2010). It is a method for testing theories by examining the association between variables (Creswell, 2014). This study adopts a correlational (predictive) research design using a survey approach. This type of design is employed when a researcher is interested in establishing some form of association or ability of a particular variable (independent variable) to predict and outcome variable (dependent variable) (Kumar, 2011; Sekaran, 2003). The survey approach allows the researcher to collect quantitative data from the respondents and analyze using both descriptive and inferential statistics. A survey method is used where a researcher is interested in assessing empirically the thoughts and opinions about a given social phenomenon via the collection of primary data from the respondents (Fisher, 2010). A survey research provides a speedy way of making an accurate assessment of a given population (Zikmund, Babin, Carr, \& Griffin, 2013). Thus, a survey method was considered appropriate for this study.

\subsection{Population and sample}

The population for this study constitutes three municipalities in Abu Dhabi. They include Abu Dhabi City Municipality, Al Ain City Municipality, Al Dhafra Region Municipality in Abu Dhabi; making a total of 256 employees at manager level. These government institutes are confronted with diverse and highly sophisticated risks that require a comprehensive risk management strategy. Inability to manage risk in this critical sector may have a devastating effect on the economy as a hub for efficient allocation of resources. Therefore, this study will inspect the influence of risk management strategies on the performance of government institutes in Abu Dhabi. Since the larger the sample sizes the better the possibility of achieving higher statistical significance, the researcher considers another method of determining higher sample size to further compliment the prior power analysis. Firstly, the researcher used the sample size table provided by Krejcie and Morgan, (1970) to determine the sample size. According to the table, a population of between 250 and 259 has a sample size of 152 . In a nutshell, a total of 163 usable questionnaires were collected from three municipalities.

\subsection{Measurement}

In this study, the data was measured using Likert scale. The questionnaires were answered on a five-point Likert scale. The Likert scale was considered appropriate for this study due to the nature of the information respondents were required to provide (Alreck \& Settle, 1995). In line with this, Krosnick and Fabrigar (1997) suggested that a 5-point Likert scale is more reliable than higher or lower scales and scale with no midpoint may increase the measurement error. In the same way, Dawes (2008) states that a 5-point scale is likely to produce better results. Below are the constructs and the measurement items:

Table 1: Construct, Sources and number of Items

\begin{tabular}{lllc}
\hline S/n & \multicolumn{1}{c}{ Construct } & Source & No of Items \\
\hline 1. & RMFI & Lai (2012) & 6 \\
2. & Risk Culture & KPMG, 2011 & 9 \\
3. & Risk management Inf. Sys & Rodriguez \& Edwards (2009) & 5 \\
4. & Risk Knowledge Sharing & Rodriguez \& Edwards (2009) & 5 \\
5. & Firm performance & Rettab, Brik, and Mellahi (2009); & 5 \\
\hline
\end{tabular}




\section{Data Analysis and Findings}

\subsection{The Measurement Model}

The validity of the research outcome depends on the reliability of the relationship among measures of the constructs. Assessment of a measurement model (outer model). The analysis deals with the components that determine how to fit the items load theoretically and link with the respective constructs. According to Hair $\mathrm{Jr}$, Sarstedt, Hopkins, and Kuppelwieser (2014), items with loadings between .40 and .70 should be considered for deletion if their removal will increase the composite reliability or AVE beyond the suggested threshold. Therefore, 30 items had loadings between .508 and .900 (see Figure 2).

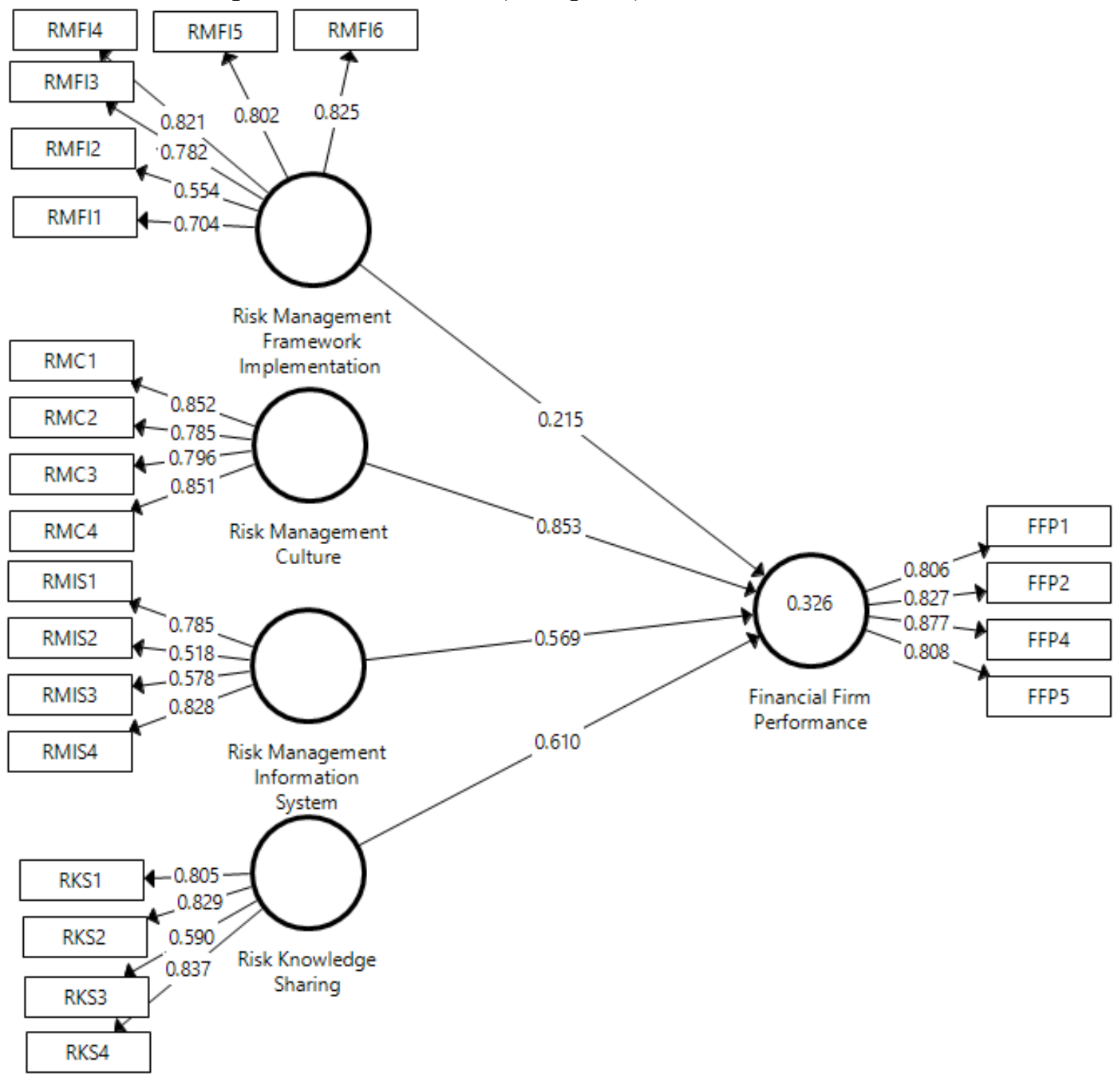

Figure 2: The Measurement Model

Discriminant validity is simply the magnitude to which a construct in a study is distinct from other constructs (Duarte \& Raposo, 2010). Following Fornell and Larcker (1981), this study assessed the discriminant validity by comparing the correlations among the variables with square roots of average variance extracted (AVE). They proposed that to attain discriminant validity, the square root of each construct's AVE should exceed the correlations for any other constructs. Table 3. compared the square root of AVE (values in boldface) with the correlations of the latent constructs. Thus, the study has achieved the discriminant validity of all the construct (Hair, Ringle, \& Sarstedt, 2011). 
Table 2: Factor loading, AVE, CR

\begin{tabular}{|c|c|c|c|}
\hline Constructs & Loadings & $\begin{array}{l}\text { Average } \\
\text { Extracted } \\
\text { AVE }\end{array}$ & $\begin{array}{c}\text { Composite } \\
\text { Reliability } \\
(\rho c) \\
\end{array}$ \\
\hline RMFI & & .588 & .895 \\
\hline RMF1 & .704 & & \\
\hline RMF2 & .544 & & \\
\hline RMF3 & .782 & & \\
\hline RMF4 & .821 & & \\
\hline RMF5 & .802 & & \\
\hline RMF6 & .825 & & \\
\hline Risk Management Culture & & .525 & .813 \\
\hline $\mathrm{RMC1}$ & .852 & & \\
\hline RMC2 & .785 & & \\
\hline RMC3 & .796 & & \\
\hline RMC4 & .851 & & \\
\hline Risk Management Information & & .553 & .830 \\
\hline System & .785 & & \\
\hline RMIS1 & & & \\
\hline RMIS2 & .518 & & \\
\hline RMIS3 & .578 & & \\
\hline RMIS4 & .828 & & \\
\hline Risk Knowledge Sharing & & .516 & .761 \\
\hline RKS1 & .805 & & \\
\hline RKS2 & .829 & & \\
\hline RKS4 & .590 & & \\
\hline RKS5 & .837 & & \\
\hline Financial Firm Performance & & .515 & .809 \\
\hline FFP1 & .806 & & \\
\hline FFP2 & .827 & & \\
\hline FFP4 & .877 & & \\
\hline FFP5 & .808 & & \\
\hline
\end{tabular}

Table 3: Independent variables correlation and Square root of AVE

\begin{tabular}{|l|c|r|r|l|l|}
\hline Constructs & FP & RMFI & RC & RMIS & RKS \\
\hline FP & $\mathbf{. 8 4 7}$ & & & & \\
\hline RMFI & -.059 & .717 & & & \\
\hline RMC & -.043 & .028 &. $\mathbf{7 1 8}$ & & \\
\hline RMIS & .189 & .127 & .033 & $\mathbf{. 7 4 4}$ & \\
\hline RKS & .329 & .148 & .056 & .253 & $\mathbf{. 8 4 1}$ \\
\hline
\end{tabular}

\subsection{The Structural Model}

The present study also applied the standard bootstrapping procedure with 500 bootstrap samples with the original number of the sample data to assess the significance of the path coefficients (Hair et al., 2014; Sarstedt et al., 2014). Sharma and Kim (2013) reported in a simulation study that PLS-SEM achieve convergence at lower sample size using 500 iterations. Figure 3 shows the structural model for the direct relationship between the exogenous variables and the endogenous variables. 


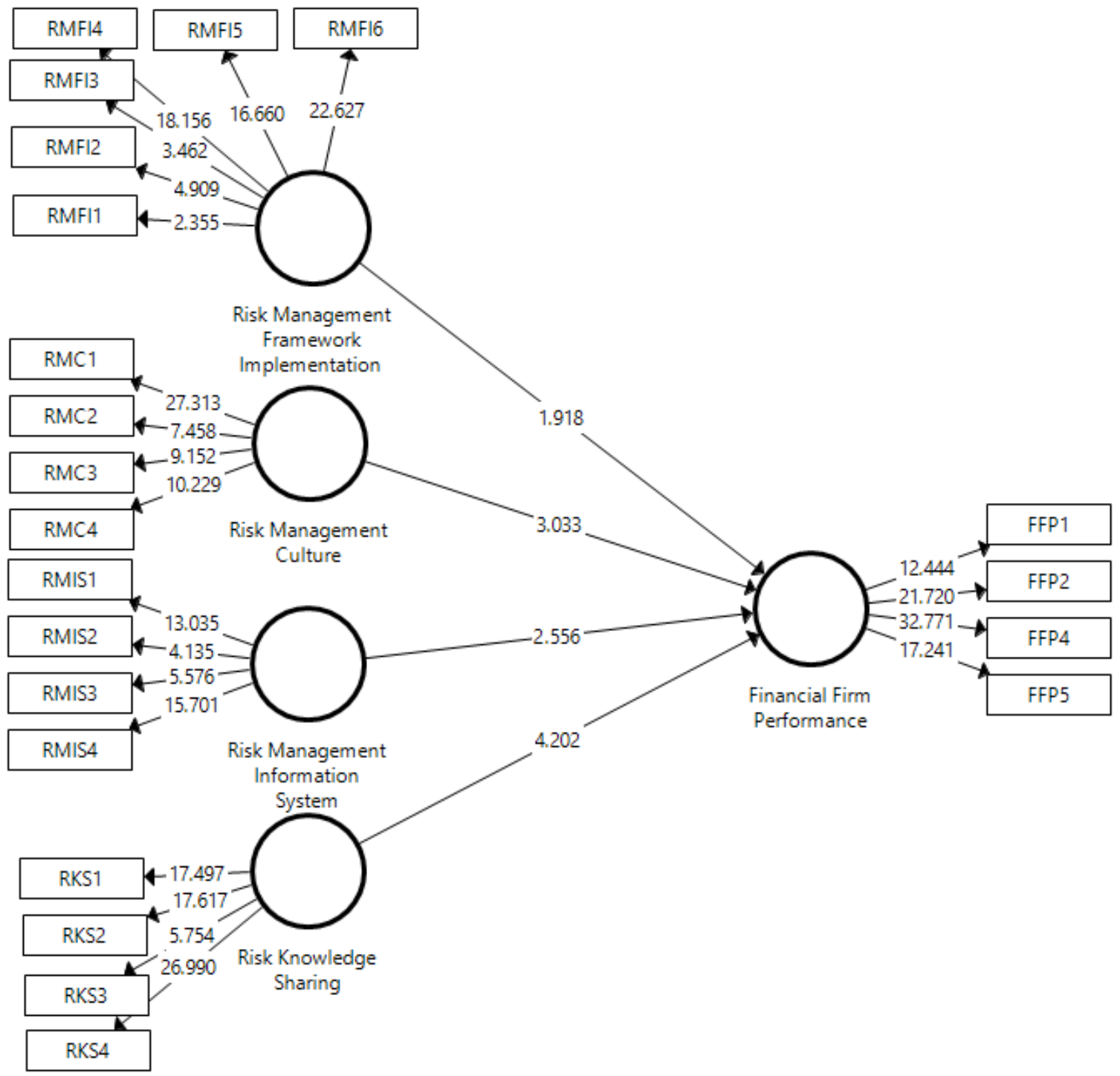

Figure 3: The Structure Model

The bootstrapping process had aided the determination of the strength of structural path relation for the test of hypotheses. The model structural assessment starts with the examination of the direct relationships between the study variables. The researcher determined the path coefficients by running PLS-SEM Algorithm while the significance of the path coefficient was assessed through PLS-SEM bootstrapping process. The study estimated the structural model in two stages. First, the study focused on the direct relationship between the exogenous variables and the dependent variables $(\mathrm{Ha} 1-\mathrm{Hb} 3)$ Table 4 presents the path coefficients, t-statistics, $\mathrm{P}$-values, and decision.

Starting with the first Hypothesis (Ha1), the results of the analysis revealed that risk management framework implementation has significant impact on on firm performance $(\beta=.186 ; \mathrm{t}=1.918 ; \mathrm{p}<.01)$. Thus, the study supported the first hypothesis. The results of the second hypothesis $(\mathrm{Hb} 1)$ indicated that risk management culture has significant impact on firm's performance $(\beta=.084 ; \mathrm{t}=3.033 ; \mathrm{p}<0.1)$. Hence, $\mathrm{Hb} 1$ is supported. Again, the result in Table 4 revealed a significant positive relationship between risk management information systems and firm's performance $(\beta=.215 ; \mathrm{t}=2.556 ; \mathrm{p}<.01)$ providing evidence to support the hypothesis $(\mathrm{Hb} 2)$. Likewise, the study provides evidence to support the fourth hypothesized relationship ( $\mathrm{Hb} 3)$ that risk knowledge sharing positively influence firm performance $(\beta=.123 ; \mathrm{t}=4.202 ; \mathrm{p}<.05)$, hence the hypothesis is supported. 
Table 4: Results of Hypotheses Testing

\begin{tabular}{clccccc} 
Hypothesis & Relation & $\begin{array}{c}\text { Beta } \\
\text { Value }\end{array}$ & $\begin{array}{c}\text { STD } \\
\text { Error }\end{array}$ & $\begin{array}{l}\text { T Value } \\
\text { P Value }\end{array}$ & Decision \\
\hline Ha1 & RMFI -> PERF & .186 & .053 & $1.918^{* * *}$ & .000 & Supported \\
Hb1 & RMC -> PERF & .084 & .059 & $3.033^{*}$ & .079 & Supported \\
Hb2 & RMI - > PERF & .215 & .054 & $2.556^{* * *}$ & .000 & Supported \\
Hb3 & RKS - PERF & .123 & .058 & $4.202^{* *}$ & .018 & Supported \\
\hline Note: ${ }^{* * *}$ Significant at 0.01 (1-tailed), $* *$ significant at $0.05\left(1-\right.$ tailed), ${ }^{*}$ significant at 0.1 (1-tailed)
\end{tabular}

The $\mathrm{R}^{2}$ value range between 0 and 1 . The closer the $\mathrm{R}$-square to 1 the more the variance explained. However, the acceptable level of $\mathrm{R}^{2}$ depends on the research discipline. Hair, Sarstedt, Ringle, \& Mena, (2012) contended that $\mathrm{R}^{2}$ value of .2 is measured high for some social science researches. Cohen (1988) categorized the $\mathrm{R}^{2}$ value of $.02, .13$, and .26 as weak, small and substantial respectively. Table 5 presents the $R^{2}$ value of the endogenous latent construct. In the present study, the result shows that the $\mathrm{R}^{2}$ value of firm performance (.321) is substantial. The value indicated that the nine variables together predict $32.70 \%$ of the variation in firm performance.

Table 5: Variance Clarified

\begin{tabular}{|c|c|}
\hline Endogenous Variable & Variance Explained $\mathbf{R}^{\mathbf{2}}$ \\
\hline Firm Performance & 0.327 \\
\hline
\end{tabular}

\section{Discussion and Conclusion}

The first objective of this study is to examine the influence of risk management framework implementation on firm performance. In this present study, risk management framework implementation is conceptualized as a structure that provides the context and the methods to deliver risk management objective of an organization. It explains the processes and the procedures for strengthening risk management strategies in an organization with a view to increasing firm performance. Risk management framework implementation is one of the essential factors that signal the implementation of risk management in organizations (Dafikpaku, 2011; Thornton, 2009).

The second hypothesis $(\mathrm{Hb} 1)$ stated that risk management culture is positively related to the performance of government institutions in Abu Dhabi. The study conceptualizes risk management culture as a system that collects, stores and disseminates risk information to various business unit to support business operations. As expected, the PLS regression result revealed a significant relationship between firm risk culture and the performance of government institutions. This finding suggests that firms with positive risk culture are more likely to have a more robust risk management program that will effectively improve firm performance. Congruent to the result of this study, previous scholars have shown that risk culture positively influences firm performance (Ernst and Young, 2014; Kimbrough \& Componation, 2009; McShane et al., 2011; Ngo \& Loi, 2008; Uzkurt et al., 2013). Nursing a solid risk culture within a business firm is fundamental to a corporate sector that is continually faced with vulnerabilities (Abd Razak et al., 2016). The study concluded that there is the need for firms in the government organisation to pay special attention to the development of positive risk culture within their domain.

Secondly, the present study also hypothesized that risk management information system is positively related to firm performance (Hb2). Drawing from the agency theory, Ravichandran et al. (2005), risk management information capability is an important strategic resource that gives a firm competitive edge. The ability of a firm to manage fortuity depends to a large extent on available information at its disposal. Hence, the finding supports the theory. Again, the firms need to put in place specific data management infrastructure that will ease risk management strategies.

Thirdly, with respect to the fourth hypothesis ( $\mathrm{Hb} 3$ ), as presumed, the PLS path modeling results revealed that risk knowledge sharing significantly influences firm performance. The study operationalized risk knowledge sharing as an organizational strategy that facilitates the management of fortuities in the organization through the exchange of risk knowledge among different business units. This particular result is consistent with existing research on knowledge sharing (Hartono \& Sheng, 2015; Hora \& Klassen, 2013; Liao et al., 2011; Rehman et al., 2015; Rodriguez \& Edwards, 2009b), who reported that knowledge sharing has a positive influence on firm performance. More specifically, some of these studies suggested the need for firms to put in place organizational systems that encourage and enhance knowledge sharing and acquisition. In this regard, risk knowledge dissemination typically enhances risk management capabilities and improve operating efficiency. Therefore, knowledge sharing as a strategic resource, if fully utilized may lead to better firm performance.

On the overall, the $\mathrm{R}^{2}$ value $(32.70 \%)$ for this study falls on the substantial category as suggested by Murphy, Myors and Wolach (2014). The $\mathrm{R}^{2}$ value for this study is relatively within the range of some related risk management strategies studies that reported low $\mathrm{R}^{2}$ value ( $\mathrm{Li}$, Wu, Ojiako, Marshall, \& Chipulu, 2014; Manab \& Ghazali, 2013; Sekerci, 2013). Similarly, the effect size (0.046) of the independent variables on the 
dependent variable was categorized as small based on Cohen (1988) criteria. This indicates that other factors apart from risk management strategies may also exert some influence on the performance of government institutions in Abu dhabi. Getting a risk management framework implementation though necessary may not be a sufficient condition for the risk management strategies to be effective in a way that it will positively influence performance. Further, the results of the descriptive indicated that only 37.40 percent have fully implemented risk management strategies while 36.80 percent and 25.80 percent are at the partial and initial implementation stages respectively. This might inform some of the reasons of low effect size as almost half of the study sample are at the initial stage of risk management framework implementation.

\section{Contributions of the Research}

The aftermath effects of the global economic meltdown have continued to pose a serious challenge to effective operations of government institutions. Risk management strategies has become a central strategy that is viewed to counter the effect of business risk through a single framework that holistically put risks in proper check. In particular, the risk concern is huge in the financial sector given the quantum of risks that surround the industry. Considering the findings of this research effort this study is of great importance both in terms of practical, theoretical and methodological implications.

The findings suggest that risk culture is a critical success factor that drives firm performance. While risk management framework implementation is critical to effective risk management it is not sufficient condition for effective implementation of risk management. To complement risk management framework risk culture has been recognized as an important element that leads to an effective and efficient risk management strategies that improve firm performance. A firm with positive risk culture is more likely to put in place a robust risk management strategy. Hence, it is recommended that a successful risk culture model needs to be put in place by government institutions to complement risk management framework for better firm performance. Regulatory agencies need to formulate policies that will instill positive risk culture in the Abu Dhabi.

Further, the study has established that risk management information system and risk knowledge sharing are important success factors that influence firm performance. It means for the government institutions to efficiently manage risk, government institutions require a well-functioning database. Hence, an effective management information system is required to enable them to analyze the frequency and severity of risk exposures. Again, government institutions must recognize the importance of risk management information to effectively analyze risk and shield the firm against uncertainties. To achieve better firm performance, government institutions should be encouraged to put in place a robust information management system for a comprehensive risk analysis and reporting. In addition, it is recommended that the government institutions need to put in place an internal risk knowledge sharing as a strategy that will improve staff capabilities to handle complex firms' operations.

Conclusively, the study identifies risk management framework and risk management success factors (risk culture, risk management information, risk knowledge sharing) as critical to improving firm performance. Hence, considering these variables together may lead to an efficient risk management strategy capable of improving firm performance.

\section{Limitation and Suggestions for Future Research}

The limitations of this study relate to the issues of self-reported measures which may lead to common method variance problems (Podsakoff et al., 2003). Even though the result of Harman's single factor technique revealed that does not exist, future studies may collect data from both regulatory agencies in addition to the government institutions to mitigate the problems of self-reported measures. another possible weakness of this current study could be traced to the fact that the study examines only the relationship between risk management framework implementation, risk management success factors, and firm performance. This current study has not examined the level of maturity of the risk management practices in the Abu Dhabi. Future studies might look at the possibility of using a capability maturity scale to gauge the level of risk management practices in the Abu Dhabi.

\section{References}

Abd Razak, N., Ab Rahman, Z., \& Borhan, H. (2016). Modeling firm resources - enterprise risk management relationships: An empirical finding using PLS- SEM. World Journal of Entrepreneurship, Management and Sustainable Development, 12(1), 35-49.

Abdullah, M. A. N., Zakuan, N., Khayon, M., Ariff, M. S. M., Bazin, N. E. N., \& Saman, M. Z. M. (2012). Adoption of enterprise risk management practices in organization: A Review. International Journal of Business and Information Technology, 2(1), 1-9.

ACI Worldwide. (2014). Taking risk management from the silo across the enterprise (Report No. ATL5537 1014). ACI worldwide Universal Paments Company. Retrieved from www.aciworldwide.comAl

AlNuaimi, M., Shaalan, K., Alnuaimi, M., \& Alnuaimi, K. (2011, December). Barriers to electronic government citizens' adoption: A case of municipal sector in the emirate of abu dhabi. In 2011 Developments in E- 
systems Engineering (pp. 398-403). IEEE.

Alreck, P. L., \& Settle, R. B. (1995). The survey research handbook: Guidelines and strategies for conducting a survey (2nd ed.). New York, NY: McGraw Hill.

Altaany, F. H. (2013). Impact of management information systems to improve performance in municipalities in north of Jordan. Interdisciplinary Journal of Contemporary Research in Business, 5(6), 429-446

Archer, D. (2002). Creating a risk management framework. CMA Management, 76(1), 16-19.

Ballantyne, R. (2013). An empirical investigation into the association between enterprise risk management and firm financial performance. Lawrence Technological University.

Beasley, B. M. S., Branson, B. C., \& Hancock, B. V. (2010a). Are you identifying your most significant risks? Strategic Finance, (November), 29-35.

Beasley, M. S., Branson, B. C., \& Hancock, B. V. (2010b). How key risk indicators can sharpen focus on emerging risks. In L. F. Mark \& J. A. Richard (Eds.), Practical Approaches for Getting Started.

Beasley, M. S., Clune, R., \& Hermanson, D. R. (2005). Enterprise risk management: An empirical analysis of factors associated with the extent of implementation. Journal of Accounting and Public Policy, 24(6), 521531.

Beasley, M., Branson, B., \& Pagach, D. (2015). An Analysis of the maturity and strategic impact of investments in ERM. Journal of Accounting and Public Policy. Retrieved from http://dx.doi.org/10.1016/j.jaccpubpol.2015.01.001

Beasley, M., Pagach, D., \& Warr, R. (2008). Information conveyed in hiring announcements of senior executives overseeing enterprise-wide risk management processes. Journal of Accounting, Auditing \& Finance, 23(3), $311-332$.

Bertinetti, G. S., Cavezzali, E., \& Gardenal, G. (2013). The effect of the enterprise risk management implementation on the firm value of European companies (No. 10/2013).

Bhagat, S., \& Bolton, B. (2008). Corporate governance and firm performance.

Bharathy, G. K., \& Mcshane, M. K. (2014). Applying a systems model to enterprise risk management. Engineering Management Journal, 26(4), 38-46.

Bouwens, J., \& Verriest, A. (2014). Putting skin in the game: managerial ownership and bank risk-taking (No. 14-070). Harvard Business Review.

Carol Liu, M. H., Tiras, S. L., \& Zhuang, Z. (2014). Audit committee accounting expertise, expectations management, and non-negative earning surprises. Journal of Accountancy and Public Policy, 33(2), 145166.

Casualty Acturial Society. (2003). Overview of enterprise risk management. Ontario Canada.

Cohen, J. (1988). Statistical power analysis for the behavioral sciences (2nd ed.).

Cohen, J. R., Holder-Webb, L. L., Nath, L., \& Wood, D. (2012). Corporate reporting of nonfinancial leading indicators of economic performance and sustainability. Accounting Horizons, 26(1), 65-90.

Creswell, J. W. (2007). Qualitative inquiry and research design: Choosing among five approaches. London: Sage Publications Inc.

Creswell, J. W. (2014). Research Design. New Delhi: Sage Publications Inc.

Creswell, J. W., \& Clark, V. L. P. (2007). Designing and conducting mixed methods research. California: Sage Publications.

Dafikpaku, E. (2011). The strategic implications of enterprise risk management: A framework. In Enterprise Risk Management Symposium (pp. 1-49). Society of Actuaries. Retrieved from www.ermsymposium.org/2011/pdf/Dafikpaku.pdf

Daud, N. W., Yazid, A. S., \& Hussin, M. H. R. (2010). The effect of chief risk officer (CRO) on enterprise risk management (ERM) practices: Evidence from Malaysia. International Business \& Economics, 9(11), 55-64.

Daud, W. N., Haron, H., \& Ibrahim, N. D. (2011). The role of quality board of directors in enterprise risk management (ERM) practices: Evidence from binary logistic regression. International Journal of Business and Management, 6(12), 205-211.

Dawes, J. (2008). Do data characteristics change according to the number of scale points used? An experiment using 5 point, 7 point and 10 point scales. International Journal of Market Research, 50(1), 61-18.

DeLoach, J., \& Thomson, J. (2014). Improving organisational performance and governance: How the COSO frameworks can help? COSO.

Demsetz, H., \& Lehn, K. (1985). The Structure of corporate ownership: Causes and consequences. Journal of Political Economy, 93(6), 1155-1177.

Dionne, G. (2013). Risk management: history, definition, and critique. Risk Management \& Insurance Review, $16(2), 147-166$.

Doherty, N. A. (2000). Integrated risk management: Techniques and strategies for managing corporate risk. New York San Francisco Washington, DC: McGRAW HILL, INC.

Duarte, P., \& Raposo, M. (2010). A PLS model to study brand preference: An application to the mobile phone 
market. In V. Esposito Vinzi, W. W. Chin, J. Henseler, \& H. Wang (Eds.), Handbook of Partial Least Squares (pp. 449-485). Springer Berlin Heidelberg.

Ernst \& Young. (2015). Board oversight of corporate culture.

Ernst and Young. (2014). Shifting focus: Risk culture at the fore front of banking.

Fadun, O. S. (2013a). Promoting enterprise risk management's adoption in business enterprises: Implications and challenges. International Journal of Business and Management Invention, 2(1), 69-78.

Fadun, O. S. (2013b). Risk management and risk management failure: Lessons for business enterprises. International Journal of Academic Research in Business \& Social Sciences, 3(2), 225-239.

Fama, E. F. (1980). Agency problems and the theory of the firm. Journal of Political Economy, 88(2), $288-307$.

Fama, E. F., \& Jensen, M. C. (1983). Agency problems and residual claims. The Journal of Law and Economics, $26(2), 327$.

Faul, F., Erdfelder, E., Lang, A.-G., \& Buchner, A. (2007). G*Power 3: A flexible statistical power analysis program for the social, behavioral, and biomedical sciences. Behavior Research Methods, 39(2), 175-91.

Feinberg, B.-J., Ostroff, C., \& Burke, W. W. (2005). The role of within-group agreement in understanding transformational leadership. Journal of Occupational and Organizational Psychology, 78(3), 471-488.

Fisher, C. (2010). Researching and writing a dissertation: A guidebook for business students (3rd ed.). England: Pearson Education Limited.

Fornell, C., \& Larcker, D. F. . (1981). Evaluating dysfunctional employee behaviors: A test of structural equation models with unobservable traditional and contingency theory postulates: The variables and measurement error. Journal of Marketing Research, 18(1), 39-50.

Gaines, C., Hoover, D., Foxx, W., Matuszek, T., \& Morrison, R. (2007). Information systems as a strategic partner in organizational performance. Jounral of Management and Marketing Research, 1-17.

Gaskin, J. (2012). Data screening. Retrieved from http://statwiki.kolobkreations.com Gates, S., Nicolas, J., \& Walker, P. L. (2012). Enterprise risk management: A process for enhanced management and improved performance. Management Accounting Quarterly, 13(3), 28-38.

Gatzert, N., \& Martin, M. (2013). Determinants and value of enterprise risk management: Empirical evidence from the literature (No. November 23, 2013). Department for Insurance Economics and Risk Management. Friedrich- Alexander-University (FAU) of Erlangen-Nürnberg.

Gibson, M. (1997). Information systems for risk management board of governors of the federal reserve system. (No. 585).

Gibson, M. S. (1998). The implications of risk management information systems for the organization of financial firms. International Finance Discussion Paper, (632).

Hafizuddin-Syah, B. A. M., Abdul-Hamid, M., Janor, H., \& Yatim, P. (2014). The implementation of enterprise risk management ( ERM ) and firm performance : Evidence from Malaysian technology firms. In The 16th Malaysian Finance Association Conference (MFA2014): Financial Systems Re-Generation: MAPS, GAPS and TRAPS.

Hair Jr, J. F., Black, J. W., Babin, B. J., \& Anderson, E. R. (2010). Multivariate aata analysis: A global perspectives (Seventh Ed.). New Jersey: Pearson Education Limited.

Hair Jr, J. F., Sarstedt, M., Hopkins, L., \& Kuppelwieser, V. G. (2014). Partial least squares structural equation modeling (PLS-SEM): An emerging tool in business research. European Business Review, 26(2), $106-121$.

Hair, J. F., Hult, G. T. M., Ringle, C., \& Sarstedt, M. (2014). A primer on partial least squares structural equation modeling (PLS-SEM). London: SAGE Publications, Incorporated.

Hair, J. F., Ringle, C. M., \& Sarstedt, M. (2011). PLS-SEM: Indeed a silver bullet. The Journal of Marketing Theory and Practice, 19(2), 139-152.

Hair, J. F., Sarstedt, M., Ringle, C. M., \& Mena, J. A. (2012). An assessment of the use of partial least squares structural equation modeling in marketing research. Journal of the Academy of Marketing Science, 40(3), 414-433.

Harrington, S., \& Niehaus, G. R. (2003). Risk Management and Insurance. USA.: Irwin/McGraw-Hill.

Hartono, R., \& Sheng, M. L. (2015). Knowledge sharing and firm performance: the role of social networking site and innovation capability. Technology Analysis \& Strategic Management, 7325(December), 1-13.

Henseler, J., \& Chin, W. W. (2010). A comparison of approaches for the analysis of interaction effects between latent variables using partial least squares path modeling: Structural equation modeling. A Multidisciplinary Journal, 17(1), 82-109.

Henseler, J., \& Fassott, G. (2010). Testing moderating effects in PLS path models: An illustration of available procedures. In V. Esposito, W. W. Vinzi, J. Chin, J. Henseler, \& H. Wang (Eds.), Handbook of Partial Least Squares: Concepts, Methods and Applications (pp. 713-735). Berlin Heidelberg: Springer.

Henseler, J., \& Sarstedt, M. (2013). Goodness-of-fit indices for partial least squares path modeling. Computational Statistics, 28(2), 565-580.

Henseler, J., Ringle, C. M., \& Sinkovics, R. R. (2009). The use of partial least squares path modeling in 
international marketing. New Challenges to International Marketing Advances in International Marketing, 20, 277-319.

Hillman, A. J. A. J., \& Dalziel, T. (2003). Boards of directors and firm performance: Integrating agency and resource dependence perspectives. Academy of Management Review, 28(3), 383-396.

HM Treasury. (2004). The orange book: Management of risk principles and concepts. London: HM Treasury. London. Retrieved from www.hm- treasury.gov.uk

Hora, M., \& Klassen, R. D. (2013). Learning from others' misfortune: Factors influencing knowledge acquisition to reduce operational risk. Journal of Operations Management, 31(1-2), 52-61.

Hoskisson, R. E., Castleton, M. W., \& Withers, M. C. (2009). Complementarity in monitoring and bonding: More compensation. Academy of Management Perspectives, (May), 57-74.

Hoyt, R. E., \& Liebenberg, A. P. (2011). The value of enterprise risk management. Journal of Risk \& Insurance, 78(4), 795-822.

Hoyt, R. E., Moore, D. L., \& Liebenberg, A. P. (2008). The value of enterprise risk management: Evidence from the US insurance industry.

Jensen, M. C., \& Meckling, W. H. (1976). Theory of the firm: managerial behavior, agency costs, and ownership structure. Journal of Financial Economics, 3(4), 305-360. Journal of Corporate Finance, 14(3), $257-273$.

Kalita, M. (2004). Enterprise-Wide Risk Management: Myth or Reality? Business Credit, 106(3), 22-23.

KPMG. (2011). Risk managment: A driver of enterprise value in emerging environment. Retrieved from https://erm.ncsu.edu/library/article/improve- challenges-survey

KPMG. (2013). Expectations of risk Management outpacing capabilities: It's time for action. Retrieved from https://www.kpmg.com

Krejcie, R. V, \& Morgan, D. W. (1970). Determining sample size for research activities. Educational and Psychological Measurement, 38, 607-610.

Krosnick, J. A., \& Fabrigar, L. R. (1997). Designing rating scales for effective measurement in surveys. In L. E. Lyberg, P. Biemer, M. Collins, E. D. De Leeuw, C. Dippo, N. Schwarz, \& D. Trewin (Eds.), Survey Measurement and Process Quality (pp. 141-164). John Wiley \& Sons.

Kumar, R. (2011). Research methodology: A step by step guide gor beginners (3rd ed.). New Delhi: Sage Publications Inc.

Lai, F. (2012). A review of enterprise risk management practices among Malaysian public listed companies. International Journal of Social, Business, Psychological, Human Science and Engineering, 6(8), 300-306.

Lai, F. W., \& Samad, F. A. (2011). Enterprise risk management framework and the empirical determinants of Its implementation. International Conference on Business and Economics Research, 1, 340-344.

Lai, F., \& Azizan, N. A. (2012). Critical review of literature on enterprise risk management and the cost of capital: The value creation perspective. African Journal of Business Management, 6(9), 3126-3133.

Lai, F.-W. (2014). Examining the dimensions of enterprise risk management implementation framework, its challenges and benefits: A study on Malaysian public listed companies. Journal of Economics, Business and Management, 2(2), 81-86.

Laisasikorn, K., \& Rompho, N. (2014). A study of the relationship between a successful enterprise risk management system, a performance measurement system and the financial performance of Thai listed companies. Journal of Applied Business and Economics, 16(2), 81-92.

Laisasikorn, K., \& Rompho, N. (2014). A study of the relationship between a successful enterprise risk management system, a performance measurement system and the financial performance of Thai listed companies. Journal of Applied Business and Economics, 16(2), 81-92.

Lam, J. (2000). Enterprise-wide risk management and the role of the chief risk officer. White Paper, ERisk. Com.

Lam, J. (2007). Enterprise risk management at Asian banks: From challenges to strategies.

Lamser, I., \& Helland, E. (2000). How the chief risk officer is taking centre stage. Balance Sheet, 8(6), $26-28$.

Laudon, K. C., \& Laudon, J. P. (2012). Management information system: Managing the digital firm. Boston, USA: Prentice Hall.

Levy, C., Lamarre, E., \& Twining, J. (2010). Taking control of organizational risk culture (Report from McKinsey \& Company). Retrieved from https://www.mckinsey.com

Li, Q., Wu, Y., Ojiako, U., Marshall, A., \& Chipulu, M. (2014). Enterprise risk management and firm value within China's insurance industry. Acta Commercii, 14(1), 1-10.

Liao, K., Ma, Z., Lee, J.-Y. J., \& Ke, K. (2011). Achieving mass customization through trust-driven information sharing: a supplier's perspective. Management Research Review, 34(5), 541-552.

Lim, E. N. K., \& Mccann, B. T. (2013). The influence of relative values of outside directors options on firm strategic risk from a multi-agent perspectives. Strategic Management Journal, 34, 1568-1590.

Lin, C.-H., Peng, C.-H., \& Kao, D. T. (2008). The innovativeness effect of market orientation and learning orientation on business performance. International Journal of Manpower, 29, 752-772.

Lin, Y. C., \& Chen, Y. M. (2007). Does innovation lead to performance? An empirical study of SMEs in Taiwan. 
Management Research News, 30(2), 115- 132.

Lin, Y., Wen, M. M., \& Yu, J. (2012). Enterprise risk management: Strategic antecedents, risk integration, and performance. North American Actuarial Journal, 16(1), 1-28.

London: Lawrence Erlbaum Associates Publisher.

Manab, N. A. (2009). Enterprise wide risk management (EWRM) implementation, compliance and value creation among public listed companies (PLCs) in Malaysia. Faculty of Business Management. Universiti Teknologi Mara, Malaysia.

Manab, N. A., \& Ghazali, Z. (2013). Does Enterprise Risk Management Create Value. Journal of Advanced Management Science Vol, 1(4), 358-362.

Manab, N. A., \& Kassim, I. (2012). Moderating effect of leadership on a success factors of enterprise-wide risk management practices. In 3rd International conference on Business and economics (pp. 1727-1741).

Manab, N. A., Kassim, I., \& Hussin, M. R. (2010). Enterprise-wide risk management (EWRM) practices: between corporate governance compliance and value. International Review of Business Research Papers, $6(2), 239-252$.

Manab, N. A., Othman, S. N., \& Kassim, I. (2012). Enterprise-wide risk management best practices: The critical success factors. International Journal of Sustainable Development, 4(3), 1-10.

Mcleod, R., \& Scheel, G. P. (2004). Management information system. New Jersey: Pearson Education.

McNish, R., Schlosser, A., Selandari, F., Stegemann, U., \& Vorholt, J. (2013). Getting to ERM: A road map for banks and other financial institutions. McKinsey \& Company.

McShane, M. K., Cox, L. A., \& Butler, R. J. (2010). Regulatory competition and forbearance: Evidence from the life insurance industry. Journal of Banking \& Finance, 34(3), 522-532.

McShane, M. K., Nair, A., \& Rustambekov, E. (2011). Does enterprise risk management increase firm value? Journal of Accounting, Auditing \& Finance, 26(4), 641-658.

Mezher, T., Goldsmith, D., \& Choucri, N. (2011). Renewable energy in Abu Dhabi: Opportunities and challenges. Journal of Energy Engineering, 137(4), 169-176.

Mikes, A., \& Kaplan, R. S. (2013). Towards a contingency theory of Enterprise Risk Management. Harvard Business School, 43.

Mikes, A., \& Kaplan, R. S. (2014). Towards a contingency theory of enterprise risk management. Harvard Business School Working Paper.

Murphy, G. B., Trailer, J. W., \& Hill, R. C. (1996). Measuring performance in entrepreneurship research. Journal of Business Research, 36, 15-23.

Murphy, K. R., Myors, B., \& Wolach, A. (2014). Statistical power analysis: A simple and general model for traditional and modern hypothesis tests (4th ed.). New York: Routledge.

Ngo, H.-Y., \& Loi, R. (2008). Human resource flexibility, organizational culture and firm performance: an investigation of multinational firms in Hong Kong. The International Journal of Human Resource Management, 19(9), 1654-1666.

Nicolas, V. (2012). Financial reform after the crisis : An early assessment.

Oladapo, A., \& Richard, O. (2012). The implications of global financial crisis on the Nigerian capital market performance: An empirical investigation ( 2000-2008 ). European Journal of Humanities and Social Sciences, 16(1), 1-18.

Onour, I. a. (2009). The global financial crisis and equity markets in middle east oil exporting countries. Retrieved from http://www.docudesk.com

Otway, H. J., \& Keil, T. (1982). Reflections on risk perceptions and policy. Risk Analysis, 2, 69-82.

Podsakoff, P. M., MacKenzie, S. B., Lee, J.-Y., \& Podsakoff, N. P. (2003). Common method biases in behavioral research: A critical review of the literature and recommended remedies. The Journal of Applied Psychology, 88(5), 879-903.

Podsakoff, P., \& Organ, D. W. (1986). Self-reports in organizational research: Problems and prospects. Journal of Management, 12(4), 531-544.

Pratt, J. ., \& Zeckhauser, R. J. (1985). Principals and agents: the structure of business. Boston.

Queensland. (2011). A Guide to Risk Management, The State of Queensland (Queensland Treasury) July .

Ram, J., \& Corkindale, D. (2014). How "critical" are the critical success factors (CSFs)? Examining the role of CSF for ERP. Business Process Management Journal, 20(1), 151-174.

Ramady, M. A. (2013). Political, economic and financial country risk. Springer, New York, NY.

Ramayah, T., Yeap, J. A. L., \& Ignatius, J. (2013). An empirical inquiry on knowledge sharing among academicians in higher learning institutions. Minerva, 51(2), 131-154.

Raminta-Pucetaite, N. (2014). The effect of leader-member exchange on organizational innovativeness: Findings from a Lithuanian public sector organization. Journal of International Scientific Publications, 8, $159-171$.

Ravichandran, T., Lertwongsatien, C., \& Lertwongsatien, C. (2005). Effect of information systems resources and capabilities on firm performance: A resource-based perspective. Journal of Management Information 
System, 21(4), 237-276.

Rehman, A., Baloch, Q. B., Afeef, M., \& Saleem, M. (2015). Relationship between information sharing and risk management practices with financial performance: Evidence from Pakistani banking sector. Journal of Managerial Sciences, 9(2), 138-146.

Reiche, D. (2010). Renewable energy policies in the Gulf countries: A case study of the carbon-neutral "Masdar City" in Abu Dhabi. Energy Policy, 38(1), 378-382.

Rejda, G. E. (2005). Risk management and insurance. Boston: Addison Wesley.

Rejda, G. E., \& McNamara, M. J. (2014). Principles of risk managment and insurance: Twelfth edition. New York: Pearson Education Limited.

Ren, H., Chandrasekar, K., \& Li, B. (2012). Moderating effects of board and managerial incentive on the relationship between $\mathrm{R} \& \mathrm{D}$ investment and firm performance- Evidence from listed manufacturing firms in China. The Journal of International Management Studies, 7(1), 41-55.

Rettab, B., Brik, A. Ben, \& Mellahi, K. (2009). A study of management perceptions of the impact of corporate social responsibility on organisational performance in emerging economies: The case of Dubai. Journal of Business Ethics, 89, 371-390.

Rockart, J. F. (1978). A new approach to defining the chief executive's information needs (No. 1008-78.).

Rodriguez, E., \& Edwards, J. (2010). People, technology, processes and risk knowledge sharing. Electronic Journal of Knowledge Management, 8(1), 139- 150.

Rodriguez, E., \& Edwards, J. S. (2008). Before and after modelling: Risk knowledge management is required. The Society of Actuaries.

Rodriguez, E., \& Edwards, J. S. (2009a). Applying knowledge management to enterprise risk management: Is there any value in using KM for ERM? Journal of Risk Management in Financial Institutions, 2(4), 427437.

Rodriguez, E., \& Edwards, J. S. (2009b). Knowledge management and enterprise risk management implementation in financial services. In Enterprise Risk Management (pp. 1-17). Retrieved from www.ermsymposium.org/2009/pdf/

Sekaran, U. (2003). Research methods for business: A skill building approach. PhD Proposal (4th ed., Vol. 1). New York: John Wiley \& Sons Ltd.

Sekaran, U., \& Bougie, R. (2010). Research methods for business: A skill building approach (5th ed.). UK: John Wiley \& Sons, Inc.

Sekaran, U., \& Bougie, R. (2013). Research methods for business: A skill building approach (5th ed.). India: Wiley.

Sekerci, N. (2013). Does enterprise risk management create value for firms ?: Evidence from Nordic countries. In 7th Nordic Econometric Meeting 2013 in Bergen (pp. 1-43).

Spender, J.-C., \& Grant, R. M. (1996). Knowledge and the firm: Overview. Strategic Management Journal, $17(\mathrm{~S} 2), 5-9$.

Strauss, A., \& Corbin, J. (1998). Basics of qualitative research: Grounded theory procedures and techniques. Newbury Park, CA: Sage Publications Inc.

Strauss, A., \& Corbin, J. (1998). Basics of qualitative research: Grounded theory procedures and techniques. Newbury Park, CA: Sage Publications Inc.

Stulz, R. M. (1996). Rethinking risk management. Journal of Applied Corporate Finance, 9(3), 8-25.

Tahir, I. M., \& Razali, A. R. (2011). The relationship between enterprise risk management (ERM) and firm value: Evidence from Malaysian public listed companies. International Journal of Economics and Management Sciences, 1(2), 32-41.

The Economist Intelligence Unit. (2014). Risk-informed innovation: Harnessing risk management in the service of innovation. Retrieved from www.gbm.hsbc.com/ /media/gbm/reports/insights/risk-informedinnovation.pdf

The World Bank. (2011). Report on the observance of standards and codes(ROSC).

The World Bank. (2013). World development report 2014: Managing risk for development.

Uzkurt, C., Kumar, R., Kimzan, S. H., \& Eminoglu, G. (2013). Role of innovation in the relationship between culture and firm performance: A study of the banking sector in Turkey. Emerald Insight, 16(1), 92-117.

Williams, A., \& Heins, M. H. (1995). Risk Management and Insurance. New York.: McGraw-Hill.

Yaraghi, N., \& Langhe, R. G. (2011). Critical success factors for risk management systems. Journal of Risk Research, 14(5), 551-581.

Zikmund, W. G., Babin, B. J., Carr, J. C., \& Griffin, M. (2013). Business research methods (8th ed.). Canada: South-Western, Cengage Learning. 